\title{
STRATEGI MARKETING MIX KOPERASI DALAM MENINGKATKAN SISA HASIL USAHA (SHU) DI PUSKOPAL KODIKLATAL SURABAYA
}

\author{
${ }^{*}$ Juwariyah $^{1}$, Anita Roosmawarni ${ }^{2}$ \\ 1,2, Prodi Manajemen, Fakultas Ekonomi dan Bisnis, Universitas Muhammadiyah Surabaya \\ *juwariyah0323@gmail.com
}

\begin{tabular}{l}
\hline Informasi Artikel \\
\hline Draft awal: Januari 2021 \\
Revisi : Februari 2021 \\
Diterima : Februari 2021 \\
Available online: Maret 2021 \\
\end{tabular}

Keywords: Strategi, Marketing Mix, dan Sisa Hasil Usaha (SHU)

Tipe Artikel : Research paper

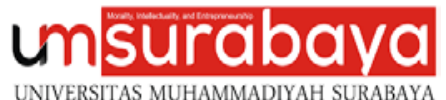

Diterbitkan oleh Universitas Muhammadiyah Surabaya

\begin{tabular}{l} 
ABSTRACT \\
\hline This study aims to determine the impact of implemention of mix marketing \\
strategy on cooperative in increasing residual income (SHU) at Puskopai \\
Kodiklatal Surabaya. This research approach used is a qualitative \\
descriptive approach and the data are collected through interviews, \\
observation and documentation. The results show that the implementation \\
of the mix marketing strategy implemented in Puskopal Kodiklatai \\
Surabaya in recent years has been declared appropriate, superior, \\
consistent, and feasible. However, during 2018 to the present period, the \\
implementation of the mix marketing strategy has not been able to run well \\
or optimally because of internal and external factors. So, there is a \\
decrease in the sales of cooperative products which also had an impact on \\
the acquisition of residual income (SHU) at Kodiklatal Cooperative, \\
Surabaya during 2018 to 2019 . \\
Penelitian ini bertujuan untuk mengetahui dampak penerapan strategi \\
marketing mix koperasi dalam meningkatkan SHU di Puskopal Kodiklatal \\
Surabaya. Pendekatan penelitian ini menggunakan pendekatan kualitatif \\
secara deskriptif dengan metode pengumpulan data melalui wawancara, \\
observasi dan dokumentasi. Hasil penelitian menunjukkan bahwa \\
penerapan strategi marketing mix yang dilakukan Puskopal Kodiklatal \\
Surabaya beberapa tahun ini dinyatakan sesuai, unggul, konsisten, dan \\
layak, namun hanya saja dalam periode tahun 2018 hingga saat ini, \\
pelaksanaan strategi marketing mix tersebut belum dapat berjalan baik atau \\
maksimal karena adanya faktor internal dan eskternal. Sehingga terjadi \\
penurunan omset penjualan produk koperasi yang juga berdampak pada \\
perolehan SHU di Puskopal Kodiklatal Surabaya mengalami penurunan di \\
tahun 2018 hingga tahun 2019.
\end{tabular}

\section{PENDAHULUAN}

Koperasi merupakan soko guru perekonomian Indonesia, sehingga keberadaannya diharapkan mampu meningkatkan kesejahteraan rakyat dan perekonomian. Secara konsepsional, koperasi sebagai badan usaha yang menampung pengusaha ekonomi lemah, yang dapat ikut serta memecahkan persoalan sosial ekonomi masyarakat (Ikhsani dan Aryoko, 2019).

Keberadaan koperasi diyakini dapat menumbuhkan dan mengembangkan potensi ekonomi kerakyatan yang mandiri, hal ini dapat dilihat dari perkembangan jumlah koperasi di Indonesia yang semakin meningkat. Berdasarkan sumber data dari Badan Pusat Statistik (BPS), 2019 jumlah koperasi di seluruh Indonesia sebanyak 152.172 unit pada 2017, tumbuh 0,66\% dibanding tahun sebelumnya. Jumlah koperasi terbanyak berada di Jawa Timur, yakni mencapai 27.683 unit atau sekitar 18\% dari total koperasi.

Maraknya persaingan antar bisnis maka perlu penetapan sebuah strategi dengan konsep pemasaran agar menjadi lebih baik dan menghasilkan pendapatan yang meningkat dalam setiap unit usahanya, sehingga apabila pendapatan usaha meningkat maka hal tersebut tentu akan meningkatkan perolehan keuntungan atau disebut Sisa Hasil Usaha (SHU) koperasi.

Puskopal Kodiklatal Surabaya merupakan salah satu koperasi yang kegiatan ekonominya berada di lingkungan Angkatan Laut dan memiliki tujuan yang sama seperti koperasi pada umumnya. Puskopal Kodiklatal selama 4 tahun terakhir ini menerapkan beberapa strategi markting mix untuk mempertahankan usaha dan berkembang dari pesaing serta bisa meningkatkan pertumbuhan Sisa Hasil Usaha di Puskopal Kodiklatal tiap tahunnya. 
Puskopal Kodiklatal Surabaya saat ini memiliki banyak bidang unit usaha yang sedang dijalankan, sebanyak 9 bidang unit usaha. Selain itu Puskopal Kodiklatal Surabaya juga merupakan koperasi sekunder yang memiliki lima primer koperasi, serta banyak menjalin kerja sama antar satuan kerja atau lembaga di TNI AL Kodiklatal ataupun diluar TNI AL Kodiklatal (sekitar 30 lembaga). Hal tersebut dapat membuktikan bahwa Puskopal Kodiklatal sebenarnya mampu memperoleh pendapatan usaha yang besar dan perolehan SHU yang besar pula.

Namun masalahnya ada beberapa strategi marketing mix usaha koperasi yang di terapkan Puskopal Kodiklatal saat ini masih belum bisa berjalan dengan baik maupun maksimal sesuai dengan apa yang di harapkan untuk dapat mempertahankan dan dapat bersaing dengan pesaing serta meningkatkan pertumbuhan SHU. Adapun perolehan SHU sebelum pajak yang tertera pada laporan keuangan koperasi berdasarkan hasil observasi yang di lakukan peneliti pada tanggal 24 Desember 2019 :

Tabel 1.1 Perolehan SHU Sebelum Pajak Tahun 2016 - 2019

\begin{tabular}{|c|lr|}
\hline TAHUN & \multicolumn{2}{|l|}{ PEROLEHAN SISA HASIL USAHA (SHU) } \\
\hline 2016 & $\mathrm{Rp}$ & $2.574 .333 .299,45$ \\
\hline 2017 & $\mathrm{Rp}$ & $2.710 .848 .598,32$ \\
\hline 2018 & $\mathrm{Rp}$ & $1.433 .115 .659,14$ \\
\hline 2019 & $\mathrm{Rp}$ & $835.297 .969,08$ \\
\hline
\end{tabular}

Sumber : Buku Himpunan Hasil RALPJ Pengurus dan Pengawas Puskopal Kodiklatal

Tabel diatas dapat dijelaskan bahwa tahun 2016 dan tahun 2017 terjadi peningkatan pertumbuhan SHU selama melakukan strategi marketing mix seperti, menambah varian produk di unit usaha yang berskala besar, dan menambah unit usaha baru yaitu unit usaha Air Tirta Kodiklatal di tahun 2016, sedangkan di tahun 2018 dan 2019 terjadi penurunan SHU yang sangat drastis.

Penurunan tersebut terjadi karena diduga adanya faktor internal dan eksternal pada saat itu. Faktor-faktor tersebut antara lain: kurangnya wawasan pengurus mengenai perkoperasian, kurang produktivitas SDM dalam pekerjaan, banyaknya karyawan yang pensiun dan keluar ditahun 2019, banyaknya pesaing dari luar lingkup TNI AL yang masuk, dan kebijakan dari pemimpin Kodiklatal sendiri dalam hal koperasi. Walaupun strategi marketing mix yang di lakukan Puskopal Kodiklatal saat ini masih belum berjalan baik, tetapi pihak koperasi pengurus ataupun anggota tetap melakukan upaya-upaya strategi lain untuk bisa mempertahankan usaha koperasi dan berkembang luas dari pesaing serta dapat meningkatkan SHU koperasi kedepannya demi menyejahterakan anggotanya. Penelitian ini bertujuan untuk, (1) Mengetahui kegiatan usaha di Puskopal Kodiklatal Surabaya, (2) Mengetahui strategi marketing mix koperasi yang diterapkan, (3) Mengetahui upaya yang dilakukan dalam peningkatan SHU koperasi, (4) Mengetahui perkembangan perolehan SHU selama 3 tahun terakhir, dan (5) Mengetahui dampak penerapan strategi marketing mix koperasi dalam meningkatkan SHU di Puskopal Kodiklatal Surabaya.

\section{LANDASAN TEORI}

\section{Koperasi}

Pengertian koperasi dalam Undang-undang Perkoperasian No. 25 Tahun 1992, yang menyebutkan bahwa koperasi adalah badan usaha yang beranggotakan orang seorang atau badan hukum dengan melandaskan kegiatannya berdasarkan prinsip koperasi sekaligus sebagai gerakan ekonomi rakyat yang berdasar atas asas kekeluargaan.

Jadi koperasi adalah badan usaha atau badan hukum yang dibentuk atas dasar keinginan dan kesadaran anggota, dikelola secara bersama, dan tanggung jawab bersama pula yang beranggotakan orang-seorang dengan bertujuan memperbaiki kesejahteraan dan ekonomi para anggota, berdasarkan atas asas kekeluargaan.

a. Tujuan dan Fungsi Koperasi

Dalam UU Perkoperasian No. 25 Tahun 1992 pasal 3 disebutkan bahwa koperasi bertujuan meningkatkan kesejahteraan anggota maupun masyarakat pada umumnya demi mewujudkan dan membangun tatanan perekonomian nasional yang maju, adil, dan makmur berlandasan Pancasila dan UUD 1945.

Untuk dapat menyediakan barang dan jasa yang dibutuhkan oleh anggota, koperasi harus menjalankan fungsi-fungsi yang menghasilkan peningkatan pelayanan anggota.

1) Mengembangkan potensi dan kemampuan ekonomi anggota dan masyarakat.

2) Berupaya mempertinggi kualitas kehidupan manusia.

3) Memperkokoh perekonomian rakyat dan mengembangkan perekonomian nasional.

4) Mengembangkan jiwa organisasi berdasar atas asas kekeluargaan dan demokrasi ekonomi.

\section{b. Prinsip Koperasi}

Prinsip koperasi adalah sebagai pedoman atau acuan yang menjadi dasar pada setiap pengelolaan koperasi, adapun prinsipnya sebagai berikut

1) Keanggotaan koperasi bersifat sukarela dan terbuka.

2) Pengelolaan dilakukan secara demokrasi. 
3) Pembagian SHU dilakukan secara adil.

4) Koperasi merupakan badan usaha mandiri yang otonom, dan independen.

5) Koperasi menyelenggarakan pendidikan dan pelatihan mengenai perkoperasian.

6) Melayani kerjasama antar koperasi maupun lembaga.

7) Koperasi bekerja untuk pembangunan berkelanjutan bagi lingkungan dan masyarakatnya melalui kebijakan dengan disepakati oleh anggota.

c. Jenis Koperasi

1) Koperasi berdasarkan tingkatannya:

a) Koperasi Primer, Koperasi yang dibentuk oleh sekurang-kurangnya 20 (dua puluh) orang.

b) Koperasi Sekunder, Koperasi Sekunder dibentuk oleh sekurang-kurangnya 3 (tiga) koperasi Primer.

2) Koperasi berdasarkan jenis usahanya:

a) Koperasi Produksi, koperasi yang menyelenggarakan kegiatan memproduksi dan menghasilkan barang dan jasa.

b) Koperasi Konsumsi, koperasi koperasi yang bidang usahanya menjual dan pengadaan barang berbagai kebutuhan pokok sehari-hari untuk memenuhi kebutuhan anggota koperasi dan masyarakat.

c) Koperasi Jasa, koperasi yang kegiatan usahanya memberikan pelayanan jasa-jasa yang dibutuhkan oleh anggotanya.।

d) Koperasi Pemasaran, koperasi yang kegiatan mendistribusi barang atau jasa yang dihasilkan oleh anggotanya agar sampai di tangan konsumen di pasar.

\section{Strategi Marketing Mix Koperasi}

Menurut Saleh dan Siska, (2015:218) strategi adalah cara untuk mencapai tujuan jangka panjang yang telah ditetapkan berdasarkan misi perusahaan. Konsep pemasaran bertujuan untuk memberikan kepuasan terhadap kebutuhan atau keinginan konsumen dengan memperoleh laba sehingga seluruh kegiatan usaha yang menganut konsep pemasaran harus diarahkan dengan baik (Lestari et al., 2019:68).

Menurut Hendar, (2010:117) menyebutkan bahwa tidak berbeda dengan bauran pemasaran perusahaan pada umumnya, unsur-unsur dalam strategi bauran pemasaran koperasi (marketing mix koperasi) adalah product (produk), place (tempat), price (harga), dan promotion (promosi). Lebih lanjut Hendar, (2010:117) menjelaskan keempat faktor tersebut saling memperkuat dan akan meningkatkan daya tarik penjualan produk atau jasa apabila terkoordinasi dengan baik.

\section{Evaluasi Strategi}

Evaluasi strategi atau penilaian strategi adalah tahap akhir dalam proses manajemen strategi dimana manajer berusaha memastikan bahwa strategi yang dipilih terlaksana dan tepat (Ridwan dan Yuli, 2018:246).

Terdapat beberapa kategori atau kriteria yang dapat menjadikan indikator kegiatan proses evaluasi strategi terhadap efektivitas dari suatu strategi dan sekaligus menyimpulkan apakah strategi marketing mix koperasi yang ada itu cukup layak (kredibel) untuk realisasikan. Menurut Rumelt dalam (Haulian et al. 2017:5381), menyebutkan terdapat empat kriteria dalam mengevaluasi strategi, yaitu:

a. Kesesuaian (Consonance), sebuah strategi harus dapat mempresentasikan respon adaptif pada lingkungan internal dan eksternal serta perubahan yang terjadi.

b. Keunggulan (Advantage), suatu strategi yang baik harus mampu menciptakan dan berkelanjutan dari suatu keunggulan kompetitif.

c. Konsisten (Consistency), suatu strategi tidak boleh saling bertentangan antara sasaran dan kebijakan.

d. Kelayakan (Feasibility, penting untuk mengetahui apakah sebuah organisasi mempunyai kemampuan, kompetensi, keterampilan, dan bakat yang diperlukan pada strategi yang diberikan, sehingga dari situlah sebuah strategi dapat dinyatakan layak atau tidaknya untuk dijalankan pada sebuah organisasi.

\section{Sisa Hasil Usaha (SHU) Koperasi}

Menurut pasal 45 ayat (1) UU Perkoperasian No. 25 Tahun 1992, pengertian Sisa Hasil Usaha (SHU) Koperasi merupakan pendapatan koperasi yang diperoleh dalam satu tahun buku dikurangi biaya, penyusutan dan kewajiban lainnya termasuk pajak dalam tahun buku yang bersangkutan.

Untuk mengukur perbandingan perolehan SHU dari tahun sebelumnya mengukur performa rasio profitabilitas pada perusahaan atau koperasi, maka dapat diketahui melalui persentase. Menurut Harahap (2015:310) dalam Pratiwi (2019:7) pertumbuhan SHU koperasi atau pertumbuhan laba adalah rasio yang menunjukkan kemampuan perusahaan meningkatkan laba bersih dibanding tahun sebelumnya.

\section{METODE PENELITIAN}

Penelitian ini menggunakan pendekatan kualitatif dengan metode deskriptif. Sumber data 
yang digunakan pada penelitian ini yaitu sumber data primer, yang diperoleh dari wawancara mendalam dan observasi, sedangkan data sekunder diperoleh dari buku-buku, catatan, dan laporan koperasi Puskopal Kodiklatal.

Teknik analisis data pada penelitian ini menggunakan model analisis kualitatif interaktif menurut Miles dan Huberman, dalam Sugiyono (2017:133), yaitu analisis data kualitatif dilakukan secara interaktif dan berlangsung secara terus menerus sampai jenuh dan tuntas dengan melalui tahap pengumpulan data, reduksi, penyajian data dan penarikan kesimpulan.

\section{HASIL PENELITIAN}

\section{Hasil Penelitian Kegiatan Usaha Puskopal Kodiklatal Surabaya}

Puskopal Kodiklatal Surabaya sejak Tahun 2016 hingga saat ini memiliki sembilan unit usaha yang masih dijalankan. Pertama, unit usaha Puskopal Kodiklatal yang bergerak di bidang operasional simpan pinjam terdapat Unit usaha UDPK-13, yaitu Unit usaha yang operasionalnya memberikan pelayanan jasa khusus simpan pinjam. Kedua, unit usaha Puskopal Kodiklatal yang bergerak di bidang operasional produksi barang terdapat Unit usaha Depo Air Tirta Kodiklatal, yaitu unit usaha yang memproduksi air mentah prigen diproses menjadi air kemasan botol dan air isi ulang. Ketiga unit usaha Puskopal yang bergerak di bidang perdagangan barang, terapat Unit Leveransir, Brumtek/Nontek, Disdag, dan Toko, yaitu unit usaha yang melakukan pembelian barang dagangan untuk dijual kembali. Dan keempat unit usaha Puskopal yang bergerak di bidang pelayanan jasa terdapat, Unit Kontruksi, Persewaan, dan Laundry, yaitu unit usaha yang opersionalnya memberikan pelayanan jasa berupa renovasi, persewaan dan pencucian.

\section{Hasil Penelitian Strategi Marketing Mix Koperasi Puskopal Kodiklatal}

Puskopal Kodiklatal Surabaya sejak dulu hingga sekarang ini menerapkan strategi marketing mix koperasi melalui strategi produk, distribusi, harga dan promosi.

Penerapan strategi produk di Puskopal Kodiklatal Surabaya dilakukan dengan cara meningkatkan kualitas barang, inovasi barang seperti sepatu PDU TNI AL, dan memperbanyak stok barang dagangan. Penerapan strategi distribusi dilakukan dengan cara membuka unit usaha baru dan membuka cabang baru Puskopal Kodiklatal seperti yang terjadi di tahun 2015 ada Unit Depo Air, dan di tahun 2018 ada Unit Minimarket serta ditahun 2019 ada Cab baru Puskopal di Bojonegoro. Penerapan strategi harga dilakukan dengan cara memberikan harga murah (penetrasi harga) dan penetapan harga grosir pada unit usaha skala besar. Penerapan strategi promosi dilakukan cara memasang plakat atau spanduk di masing-masing unit usaha, pemeran barang atau sponsor saat acara tertentu, dan menawarkan barang dan jasa secara langsung (personal selling).

\section{Hasil Penelitian Upaya Peningkatan SHU di Puskopal Kodiklatal}

Dalam mencapai keberhasilan koperasi yaitu meningkatkan perolehan SHU koperasi, Puskopal Kodiklatal Surabaya sering dihadapkan beberapa faktor pendukung dan penghambat yang berasal dari lingkungan internal dan eksternal koperasi. Adapun beberapa contoh faktor penghambat Puskopal Kodikatal Surabaya di tahun 2018 yang menyebabkan penurunan kinerja koperasi yaitu kurangnya jumlah Sumber Daya Manusia serta minimnya pengetahuannya tentang bisnis dan peroperasian, kurangnya sarana prasarana, terbatasnya modal, banyaknya pesaing luar CV/PT yang masuk di Kodiklatal, dan lain-lain.

Sehingga dalam hal tersebut pimpinan Puskopal Kodiklatal Surabaya berbagai upaya melalui Rencana Kerja Jangka Pendek dengan Program 100 hari kerja dan Rencana Kerja Jangka Panjang yang sudah tertera dalam RK dan RAPB TB 2020.

\section{Hasil Penelitian Perkembangan Perolehan SHU Selama 3 Tahun Terakhir di Puskopal Kodiklatal}

Perkembangan perolehan SHU Puskopal Kodiklatal Surabaya selama 3 tahun terakhir mengalami naik turun. Dapat dilihat pada Tabel dibawah ini:

Tabel 4.5 Pertumbuhan (Trend)
\begin{tabular}{|c|cr|c|c|}
\hline \multirow{2}{*}{ Tahun } & \multirow{2}{*}{ SHU (Rp) } & \multicolumn{2}{|c|}{ Pertumbuhan } \\
\cline { 4 - 5 } & & & Trend $(\%)$ & Selish $(\%)$ \\
\hline 2016 & $\mathrm{Rp}$ & $2.098 .130 .799,45$ & 100 & 100 \\
\hline 2017 & $\mathrm{Rp}$ & $2.188 .491 .477,23$ & 104,3 & 4,3 \\
\hline 2018 & $\mathrm{Rp}$ & $1.157 .606 .034,14$ & 52,9 & $-47,1$ \\
\hline 2019 & $\mathrm{Rp}$ & $675.656 .594,08$ & 58,4 & $-41,6$ \\
\hline
\end{tabular}

Sumber: Buku Peta dan Profil Kopal Kodiklatal Gabungan Smt. 1 \& II Tahun 2019

Tabel diatas dapat dijelaskan bahwa perkembangan perolehan SHU pada tahun 2017 jika dibandingkan dengan tahun 2016 maka terjadi pertumbuhan SHU sebesar 4,3\%, sedangkan perolehan SHU tahun 2018 jika dibandingkan dengan tahun 2017 maka terjadi penurunan SHU sangat signifikan yaitu sebesar 47,1\% , dan jika tahun 2019 dibandingkan dengan tahun 2018 maka terjadi penurunan SHU sebesar $41,6 \%$. 


\section{Hasil Penelitian Dampak Penerapan Strategi Marketing Mix Koperasi di Puskopal Kodiklatal Surabaya}

Dampak penerapan strategi marketing mix pada peningkatan SHU di Puskopal Kodiklatal Surabaya diketahui melalui evaluasi strategi menurut Rumelt dalam (Haulian et al. 2017:5381) melalui hasil wawancara dengan beberapa informan yang menyatakan bahwa strategi marketing mix koperasi yang diterapkan Puskopal Kodiklatal telah sesuai, unggul, konsisten, dan layak bagi Puskopal Kodiklatal Surabaya untuk meningkatkan SHU koperasi. Hanya saja ditahun 2018 hingga saat ini terdapat kurangnya kemampuan atau kendala yang berasal dari lingkungan internal dan eksternal di Puskopal Kodiklatal Surabaya sehingga membuat pelaksanaan strategi kurang maksimal. Contohnya seperti kurang maksimalnya penerapan strategi promosi karna kurangnya SDM yang memadai dan contoh lainnya yaitu kurang maksimalnya penerapan strategi harga yang murah karna ketidakstabilan harga barang dipasaran yang sering kali mengalami kenaikan harga yang secara tiba-tiba atau musiman.

\section{PEMBAHASAN}

\section{Pembahasan Kegiatan Usaha di Puskopal Kodiklatal Surabaya}

Puskopal Kodiklatal Surabaya memiliki berbagai macam unit-unit usaha yang sedang dikelolahnya dengan tujuan untuk memenuhi kebutuhan anggota koperasi maupun masyarakat di Kodiklatal Surabaya yang beraneka macam. Hingga saat ini unit usaha yang berjalan di Puskopal Kodiklatal Surabaya terdapat sembilan unit usaha, yang terdiri dari Unit UDPK-13, Depo Air Tirta Kodiklatal, Leveransir, Brumtek/Nontek, Toko Atribut TNI AL, Disdag, Jasa Kontruksi, Laundry dan Persewaan. Unit usaha Puskopal Kodiklatal Surabaya yang kegiatan usahanya bergerak dibidang operasional simpan pinjam terdapat Unit UDPK-13. Unit usaha Puskopal Kodiklatal Surabaya yang kegiatan usahanya bergerak dibidang operasional memproduksi barang terdapat Unit Depo Air Tirta Kodiklatal. Unit usaha Puskopal Kodiklatal Surabaya yang kegiatan usahanya bergerak dibidang operasional perdagangan barang terdapat Unit Leveransir, Brumtek/Nontek, Disdag dan Toko Atribut TNI. Terakhir unit usaha Puskopal Kodiklatal Surabaya yang kegiatan usahanya bergerak dibidang operasional pelayanan jasa terdapat Unit Jasa Kontruksi, Laundry dan Persewaan. Sehingga dalam hal ini sesuai dengan UU Perkoperasian No. 25 Tahun 1992 Bab VIII, menyebutkan bahwa kegiatan usaha koperasi yang dibentuk haruslah berkaitan langsung dengan kepentingan anggota dan untuk memenuhi kebutuhan masyarakat.

\section{Pembahasan Strategi Marketing Mix Koperasi di Puskopal Kodiklatal}

Strategi marketing mix di Puskopal Kodiklatal Surabaya sudah dijalankan beberapa tahun ini untuk dapat meningkatkan penjualan produk koperasi tepatnya sejak tahun 2016 hingga sekarang yaitu melalui strategi produk, strategi distribusi, strategi harga dan strategi promosi, sebagaimana telah di paparkan pada landasan teori bahwa keempat faktor tersebut saling memperkuat dan akan meningkatkan daya tarik penjualan produk atau jasa apabila terkoordinasi dengan baik.

Pelaksanaan strategi produk di Puskopal Kodiklatal dilakukan dengan cara meningkatkan kualitas barang, inovasi produk, dan memperbanyak stok barang dagangan. Pelaksanaan strategi distribusi di Puskopal Kodiklatal Surabaya dilakukan dengan cara membuka unit usaha baru dan membuka cabang baru Puskopal Kodiklatal. Pelaksanaan strategi harga di Puskopal Kodiklatal Surabaya dilakukan dengan cara pemberian harga murah atau penetrasi harga dan penetapan harga grosir. Dan pelaksanaan strategi promosi di Puskopal Kodiklatal Surabaya dilakukan dengan cara memasang plakat atau banner, melakukan pemeran barang atau memberikan sponsor barang sebagai dukungan suatu acara, dan melakukan pewaran barang secara langsung kepada konsumen (personal selling).

\section{Pembahasan Upaya Peningkatan Perolehan SHU Puskopal Kodiklatal}

Dalam memajukan usaha koperasi dari tahun ke tahun maka Puskopal Kodiklatal Surabaya melakukan berbagai upaya atau tindakan korektif secara terus menerus dalam menghadapi perubahan kondisi lingkungan internal dan eksternal yang menjadi faktor pendukung dan penghambat dalam mencapai sebuah keberhasilan koperasi. Sebagaimana yang dipaparkan pada landasan teori bahwa keadaan suatu obyek harus dilaksanakan secara kontinu bukan hanya berakhir pada periode tertentu atau hanya saat terjadinya masalah (Ridwan dan Yuli, 2018: 246).

Sejak tahun 2018 hingga saat ini Puskopal Kodiklatal Surabaya telah mengalami penurunan kinerja koperasi, hal ini terjadi karena adanya faktor internal dan eksternal yang menjadi penghambat. Faktor internal dan eksternal yang menjadi penghambat kinerja koperasi saat ini di Puskopal Kodiklatal meliputi, kurangnya jumlah Sumber Daya Manusia serta minimnya pengetahuannya tentang bisnis dan peroperasian, kurang koordinasi antar pimpinan, kurang mendukungnya sarana prasarana, 
terbatasnya modal untuk membuka usaha baru, banyaknya pesaing luar CV/PT yang masuk di Kodiklatal, banyaknya pelaku-pelaku usaha yang muncul dilingkungan Kodiklatal, kurang stabilnya perekonomian, dan adanya peraturan kebijakan dari pimpinan Kodiklatal terkait koperasi. Sehingga dalam hal tersebut pimpinan Puskopal Kodiklatal Surabaya saat ini melakukan upaya untuk meningkatkan SHU koperasi yaitu melalui Rencana Kerja Jangka Pendek dengan Program 100 hari kerja terdiri dari membuka usaha minimarket, perbaikan sarana prasarana, serta pembenahan SDM. Serta Rencana Kerja Jangka Panjang yang sudah tertera dalam RK dan RAPJ TB 2020 sebagai pedoman kerja Puskopal kedepannya antara lain, meliputi pembenahan di bidang kebijakan dan strategi, bidang Idiil dan administratsi koperasi, bidang usaha, bidang sekretariat, dan bidang keuangan.

\section{Pembahasan Perkembangan Perolehan SHU Selama 3 Tahun Terakhir di Puskopal Kodiklatal}

Perkembangan perolehan SHU Puskopal Kodiklatal Surabaya selama 3 tahun terakhir mengalami naik turun. Perolehan pada Tahun 2016 perolehan SHU mencapai Rp. 2.096.130.799,45,pada Tahun 2017 perolehan SHU mencapai Rp. 2.188.491.473,23,- pada Tahun 2018 perolehan SHU mencapai Rp. 1.157.606.043,14,- dan terakhir pada Tahun 2019 perolehan SHU mencapai Rp. 675.656.5 94,08,-. Besarnya perolehan SHU tersebut bersumber pada penambahan SHU seperti pendapatan dari kegiatan usaha, dan simpanan modal anggota dan adanya pengurangan SHU seperti biaya personil, pajak, operasional dan lainnya pada periode tertentu. Sehingga perkembangan perolehan SHU tahun 2017 dibandingkan dengan tahun 2016 maka terjadi pertumbuhan SHU sebesar 4,3\%, sedangkan perolehan SHU tahun 2018 dibandingkan dengan tahun 2017 maka terjadi penurunan SHU sebesar 47,1\% , dan tahun 2019 dibandingkan dengan tahun 2018 maka terjadi penurunan SHU sebesar 41,6\%.

\section{Pembahasan Dampak Penerapan Strategi Marketing Mix Koperasi di Puskopal Kodiklatal Surabaya}

Strategi marketing mix yang diterapkan Puskopal Kodiklatal Surabaya selama ini dinyatakan sesuai, unggul, konsisten, dan layak. Namun hanya saja dalam periode tahun 2018 hingga saat ini pelaksanaan penerapan strategi marketing mix belum dapat berjalan dengan baik atau maksimal karena kurangnya kemampuan dan adanya kendala yang berasal dari faktor internal dan eksternal yang menghambat pelaksanaan sebuah strategi pada periode tersebut. Sehingga dalam penerapan strategi marketing mix di Puskopal Kodiklatal Surabaya pada tahun 2016 hingga 2017 mengakibatkan peningkatan perolehan SHU koperasi sebesar 4.3\% sedangkan pada tahun 2018 hingga tahun 2019 mengakibatkan penurunan perolehan SHU sebesar 47,1\% dan 41,6\% jika dibandingkan dengan tahun sebelumnya.

Dengan demikian hasil penelitian menunjukkan bahwa penerapan strategi marketing mix sangat berpengaruh signifikan terhadap perkembangan perolehan SHU koperasi di Puskopal Kodiklatal Surabaya, namun hanya saja dalam periode tahun 2018 hingga saat ini pelaksanaan strategi marketing mix tersebut belum dapat berjalan baik atau maksimal karena kurangnya kemampuan atau adanya kendala yang berasal dari faktor internal dan eksternal koperasi di Puskopal Kodiklatal Surabaya.

Hal tersebut ternyata membuktikan adanya kebenaran dari suatu teori yang telah dipaparkan pada landasan teori yaitu menurut Hendar, (2010:117) dalam bukunya menjelaskan keempat faktor pemasaran (produk, tempat, harga dan promosi) saling memperkuat dan akan meningkatkan daya tarik penjualan produk atau jasa apabila terkoordinasi dengan baik. Pernyataan tersebut juga sependapat menurut Saleh dan Siska, (2015) bahwa dalam menentukan strategi koperasi, koperasi harus mempertimbangkan secara cermat hal-hal sebagai berikut: kekuatan internal koperasi, kelemahan internal koperasi, kesempatan peluang bisnis yang tersedia, dan hambatan ataupun kendala bisnis yang diperkirakan mengganggu pencapaian tujuan koperasi.

Artinya yang membuat pelaksanaan strategi di Puskopal Kodiklatal Surabaya kurang bisa berjalan dengan baik dan maksimal yang terjadi di tahun 2018 hingga sekarang terjadi karena kurang terkoordinasi dengan baik antara program strategi dengan kondisi lingkungan Puskopal Kodiklatal Surabaya atau lebih tepatnya kurang memperhatikan secara cermat faktor internal dan eksternal yang mendukung serta menghambat pelaksanaan strategi tersebut. Sehingga hal ini berdampak pada penurunan atas penjualan produk koperasi yang mengakibatkan perolehan SHU di Puskopal Kodiklatal Surabaya juga mengalami penurunan di tahun 2018 hingga tahun 2019.

\section{SIMPULAN DAN SARAN}

\section{Simpulan}

1. Puskopal Kodiklatal Surabaya pada Tahun 2016 hingga saat ini memiliki 9 bidang unit usaha yang terdiri dari Unit Udpk-13, Unit Depo Air Tirta Kodiklatal, Unit Leveransir, Unit Brumtek/Nontek, Unit Toko, Unit Disdag, Unit Kontruksi, Unit Persewaan, dan Unit Jasa Laundy. Unit-Unit usaha tersebut kegiatan 
usahanya ada yang bergerak di bidang operasional usaha simpan pinjam, memproduksi barang, perdagangan barang dalam skala besar maupun eceran, dan pelayanan jasa.

2. Puskopal Kodiklatal Surabaya sejak tahun 2016 hingga saat ini menerapkan strategi marketing mix untuk meningkatkan Sisa Hasil Usaha (SHU) koperasi, yang meliputi: strategi produk yaitu inovasi, meningkatkan kualitas produk, dan memperbanyak stok barang. Strategi distribusi yaitu membuka unit usaha baru dan membuka cabang baru. Strategi harga yaitu melalui penetrasi harga atau pemberian harga murah, dan penetapan harga grosir. Dan strategi promosi yaitu pemasangan plakat, pameran barang atau sponsor saat ada acara tertentu, dan menawarkan produk (personal selling).

3. Upaya yang dilakukan Puskopal Kodiklatal Surabaya saat ini untuk meningkatkan SHU yaitu dalam Jangka Pendek melalui program 100 hari kerja terhitung tanggal 27 mei 2020 yang programnya meliputi memperbaiki SDM, membuka unit usaha baru Minimarket, dan memperbaiki sarana prasarana. Sedangkan dalam jangka panjang yang tertera pada RK dan RAPB TB. 2020 upaya Puskopal Kodiklatal berfokus dalam bidang kebijakan dan strategi, bidang usaha, bidang sarana prasarana, bidang keuangan, dan bidang rencana anggaran pendapatan dan belanja.

4. Perkembangan perolehan Sisa Hasil Usaha (SHU) di Puskopal Kodiklatal Surabaya selama tiga tahun terakhir mengalami naik turun, yaitu pada Tahun 2016 perolehan SHU mencapai Rp. 2.096.130.799,45,- pada Tahun 2017 perolehan SHU mencapai Rp. 2.188.491.473,23,-- pada Tahun 2018 perolehan SHU mencapai Rp. 1.157.606.043,14,- dan terakhir pada Tahun 2019 perolehan SHU mencapai Rp. 675.656.5 94,08,-.

5. Strategi marketing mix yang diterapkan Puskopal Kodiklatal Surabaya selama ini dinyatakan sesuai, unggul, konsisten, dan layak. Namun hanya saja dalam periode tahun 2018 hingga saat ini pelaksanaan penerapan strategi marketing mix belum dapat berjalan dengan baik atau maksimal karena kurangnya kemampuan dan adanya kendala yang berasal dari faktor internal dan eksternal koperasi. Sehingga berdampak pada perolehan SHU di tahun 2016 hingga 2017 mengakibatkan peningkatan perolehan SHU koperasi sebesar 4.3\% sedangkan pada tahun 2018 hingga tahun 2019 mengakibatkan penurunan perolehan SHU sebesar $47,1 \%$ dan $41,6 \%$ jika dibandingkan dengan tahun sebelumnya.

\section{Saran}

1. Disarankan untuk merekrut tenaga kerja yang benar-benar profesional atau pengajuan pengisian personil PNS/Mil pada pimpinan Kodiklatal yang mempunyai pemahaman terkait ilmu ekonomi bisnis dan mempunyai soft skill di bidang teknologi.

2. Perlu adanya penyelenggaraan Pelatihan Perkoperasian secara rutin yang bermateri tentang tata cara pengelolaan perkoperasian, strategi berbisnis, dan perkembangan teknologi yang maju.

3. Perlu disarankan adanya pendekatan dengan mitra kerja maupun anggota agar dapat menjalin kerja yang baik.

4. Perlu disarankan adanya perambil alihan aset Puskopal Kodiklatal Surabaya yang tidak terlalu penting dan aset lainnya yang tidak terpakai dijual untuk dijadikan modal kerja sebagai rencana kerja dan digantikan untuk memperbaiki sarana prasana yang kurang layak.

5. Disarankan kepada pihak Puskopal Kodiklatal Surabaya agar melakukan perampingan atau pengurangan unit usaha yang ada dengan cara memberhentikan kegiatan operasional salah satu unit usaha yang sekiranya tidak dapat berkontribusi lebih atau memberikan keuntungan besar bagi koperasi, serta memfokuskan pengelolaan di unit usaha yang sekiranya berkontribusi besar.

6. Disarankan kepada pihak koperasi agar menentukan besarnya persentase keuntungan yang dinginkan pada setiap barang yang akan dijual sehingga dapat menentukan besarnya harga penjualan suatu barang maupun jasa koperasi dari harga pokok penjualan atau dari harga pembelian barang.

\section{DAFTAR PUSTAKA}

Badan Pusat Statistik (BPS). (2019). Jumlah Koperasi Aktif Menurut Provinsi. Diakses 22 Juli 
https://www.bps.go.id/dynamictable/2019/07/2 2/1643/jumlah-koperasi-aktif-menurutprovinsi-2006-2017.html

Harahap, S. S. (2015). Analisis kritis atas laporan keuangan / Sofyan Syafri Harahap (Cetakan ke). Jakarta : Rajawali Pers, 2015.

Haulian, F. I. (2017). Evaluasi Strategi Dinas Tenaga Kerja Dalam Penyaluran Tenaga Kerja di Kota Samarinda. Administrasi Negara, 5, 53785392.

Hendar S.E., M. S. (2010). Manajemen Perusahaan Koperasi (Pokok-pokok Pikiran mengenai Manajemen dan Kewirausahaan Koperasi) (Novietha Indra Sallama (ed.)). Erlangga.

Ikhsani, M.M., dan M., dan P. Aryoko, Y. (2019). Strategi Pengembangan Koperasi Dalam Upaya Membangun Kesejahteraan Masyarakat. DERIVATIF : Jurnal Manajemen, 13(2).

Lestari, W., Musyahidah, S., dan Istiqamah, R. (2019). Strategi Marketing Mix Dalam Meningkatkan Usaha Percetakan Pada CV. Tinta Kaili dalam Perspektif Ekonomi Islam. Jurnal Ilmu Ekonomi Dan Bisnis Islam, 1(1), 63-84.

Menteri Koperasi dan Usaha Kecil Menengah Republik Indonesia. (1992). Undang-Undang
Republik Indonesia Nomor 25 Tahun 1992. Tentang Perkoperasian, 1-28.

Miles, B. M. dan M. H. (1992). Analisis Data Kualitatif Buku Sumber Tentang Metodemetode Baru. UIP.

Pratiwi, D. (2019). Strategi Pengembangan Koperasi Dalam Meningkatkan Laba ( Studi Kasus Koperasi Pegawai Republik Indonesia ( KPRI) Guyub Rukun Kecamatan Banjarmangu , Kabupaten Banjarnegara ). 1-20.

Ridwan dan Yuli. (2018). Strategi Dalam Penyusunan Business Plan. Formulasi, Implementasi Dan Evaluasi Strategi Dalam Penyusunan Business Plan Pada Pt. Bosowa Propertindo, 244-253.

Rumelt P. Richard. (1980). The Evaluasi Of Business Strategy. McGraw-Hill.

Saleh, Y., dan Siska, I. (2015). Strategi Pengembangan Koperasi Unit Desa (KUD) Berkat Telaga Kecamatan Telaga Kabupaten Gorontalo Yanti Saleh; Siska Ismail Jurusan Agribisnis Fakultas Pertanian Universitas Negeri Gorontalo. Jurnal Perspektif Pembiayaan Dan Pembangunan Daerah Vol. 2, 4, 217-222.

Sugiyono. (2017). Metode Penelitian Kuantitatif, Kualitatif dan RdanD (Ghozali). CV Alfabeta. 